\title{
Hugo de San Víctor. Didascalicon de studio legendi (el afán por el estudio) Madrid, BAC, 2011.
}

El periodo de constitución y adaptación de la enciclopedia antigua a las necesidades de la sociedad medieval que comenzó en el Renacimiento carolingio supuso la suma de los contenidos desarrollados en Oriente con los conservados por tradición. La síntesis de esa colección cultural aportaría una doctrina sobre la naturaleza, el hombre y Dios mejor integrada, y la incorporación de las artes prácticas, económicas y mecánicas, aplicable a las comunidades monásticas primero, y después a los grupos ciudadanos.

En la recuperación de la cultura antigua durante la Edad Media, la Escuela de San Víctor, junto con la tradición del comentario y copia desarrollada en Chartres, tuvo una destacadísima importancia. Tanto en estudio de la lógica como en el campo de la filosofía el conjunto de contenidos de la enseñanza era relativo a una idea del hombre y de la naturaleza en la que se desarrollaba su vida. Hugo de san Víctor en Didascalicon seu de studio legendi muestra, en consonancia con otras obras enciclopédicas medievales, el saber profano que hunde sus raíces en el conocimiento heredado de los griegos, y la preparación para el estudio de las Sagradas Escrituras.

La obra, escrita en un latín elegante, es anterior a 1125 o 1130 y se transmitió en ciento veinticinco manuscritos. Su exposición está fundada en definiciones y conceptos, que nos permiten conocer la variedad de sus fuentes. Como tratado pedagógico marcó un hito en una concepción del conocimiento más amplia y diversificada, que abarcara la totalidad del saber humano. La subjetividad presente en algunas cuestiones hace difícil que pueda ser considerada todavía una forma de enciclopedia. Propone un modelo de maestro y de estudiante, al que exhorta a un comportamiento humilde y dócil para abrazar la sabiduría. La disposición de los estudios está tutelada por la filosofía como acceso al saber, por la lógica y por la teología, que comenzó a ser la ciencia tutelar por excelencia. El impulso de esta obra fue anterior al prestigio de los catálogos de estudios que se difundieron a través de la expansión del Islam medieval, el de Al-Farabi o la lógica de Algazel o el averroísmo. Entre 1170 y 1270 se fueron difundiendo varias obras, traducidas al latín, que trataban el tema de la clasificación de los conocimientos. Entre los más influyentes debemos citar De scientiis y De ortu scientiarum de Al-Farabi; su traductor compuso una obra titulada De diuisione philosophiae con esa inspiración. La Universidad de París fue el centro receptor de estos modelos de ciencia.

Por eso esta obra es una aplicación tardía del modelo de formación que desde la Antigüedad tardía recorre la cultura monástica, antes del establecimiento de las universidades. Las constituciones universitarias propiciaron la adaptación de todas estas propuestas culturales a una sociedad muy distinta, con una gran diversidad y necesitada de hombres preparados para la administración de los Estados. La cultura bíblica se asoció rápidamente a las corrientes orientales renovadas a partir de finales del siglo XII, y la vieja sabiduría de los grandes imperios milenarios volvió a fecundar las mentes educadas en la filosofía clásica. En la concepción clásica de la enseñanza, la distinción entre la cultura del hombre libre y las artes desempeñadas por esclavos limitó el desarrollo de métodos de aplicación que habrían facilitado el progreso material. El auge del comercio y de la pequeña burguesía medieval necesitaba una cultura práctica, una sabiduría práctica, y un deleite en el ejercicio del intelecto, tanto para la comprensión de la relación con Dios como para beneficiarse de la riqueza de este mundo.

En la descripción de las artes, Boecio es el autor más citado, una referencia necesaria sobre todo para los conocimientos comprendidos en el quadrivium. Los saberes técnicos están apenas esbozados, pero se abren paso en "siete ciencias" que resultan de la división de la mecánica. Entre ellas se menciona la medicina, pero también se encuentran las actividades económicas principales como la agricultura, la caza, la navegación y la fabricación de lana y del armamento. La séptima considerada es el arte teatral, característica que se explica por una probable reminiscencia de noticias de la Antigüedad (recordemos las referidas por San Isidoro en Origenes). El número siete de los planetas, de los días de la semana, de las virtudes y de los 
vicios, agrega de manera sorprendente esa colección de saberes, que figura una similitud con las siete artes de trivium sumado con el quadrivium.

Una propuesta que abrió camino a la modificación de los estudios fue la formulada después por Godofredo de San Víctor (c. 1125-1194) bajo la apariencia alegórica: tras el trivium y el quadrivium el alumno se incorporaba al cauce de las artes prácticas (ética, economía y política) para pasar por fin al gran río de los estudios teológicos.

Todavía en este tratado de iniciación de Hugo de San Víctor (1096-1141) no se adivina la jerarquía de saberes que la etapa de madurez de la cultura islámica en contacto con Europa pudo aportar a la restauración del avance científico. En una obra temprana, Epitome Dindimi in philosophiam, Hugo explica las divisiones de la filosofía como remedio de los tres defectos del hombre: la ignorancia del bien, el deseo del mal, y la debilidad de su ser mortal. Las artes teóricas suministran la sabiduría necesaria para superar la ignorancia del bien; las prácticas enseñan la virtud de desear hacer el bien; y las mecánicas, la habilidad para sobrevivir. Por eso la educación, según este criterio, debe satisfacer esas tres necesidades humanas. Pedro Abelardo (1079-1142), contemporáneo y algo mayor que Hugo, desarrolló y estructura la relación entre entendimiento y voluntad, partiendo de la enseñanza de la prestigiosa Escuela de Chartres.

Sin embargo, el fin esencial del tratado medieval era la exégesis (cuestión en la que se interna a partir del libro quinto) y una ascesis hacia la contemplación. Esta idea del conocimiento todavía influyó en pensadores del siglo XIII, como Raimundo Lulio, San Buenaventura, o Alberto Magno. María Luisa Arribas ha realizado la edición bilingüe y Carmen Muñoz, autora de una tesis sobre el pensamiento pedagógico de este autor medieval, ha escrito la introducción a la obra. El comentario se podría haber desarrollado sobre la progresión de los modelos formados por las escuelas para el diseño de una didascalia aplicable a los estudios eclesiásticos y civiles.

María Asunción Sánchez Manzano

Universidad de León 